Supplement of

\title{
Growth of nucleation mode particles in the summertime Arctic: a case study
}

Correspondence to Megan D. Willis (megan.willis@mail.utoronto.ca)

\section{Methods}

\section{$1.1 \quad$ HR-ToF-AMS measurements}

\subsubsection{Characterization of the pressure controlled inlet (PCI)}

The HR-ToF-AMS sampled behind a PCI similar to that described by Hayden et al. (2011). The transmission of ammonium nitrate $\left(\mathrm{NH}_{4} \mathrm{NO}_{3}\right)$ particles over the size range of $70-800 \mathrm{~nm}$ (calculated vacuum aerodynamic diameter, $\mathrm{d}_{\mathrm{va}}$ ) through the HR-ToF-AMS aerodynamic lens was investigated in order to determine the transmission of particles in the PCI. In these experiments a solution of $\mathrm{NH}_{4} \mathrm{NO}_{3}$ was atomized, the aerosol flow was dried and sent to a differential mobility analyser (DMA) for size selection. Solution concentrations were varied such that doubly charged particles accounted for less than $10 \%$ of the total mass exiting the DMA. At each size, the AMS-derived ammonium nitrate mass was compared to the mass calculated based upon condensation particle counter (CPC) number concentrations. These experiments were done immediately following an HR-ToF-AMS ionization efficiency calibration with $\mathrm{NH}_{4} \mathrm{NO}_{3}$. Results indicate negligible loss of particles in the PCI within experimental uncertainty, and lens transmission curves similar to other AMS instruments. Similar results were obtained for ammonium sulfate particles over a smaller size range.

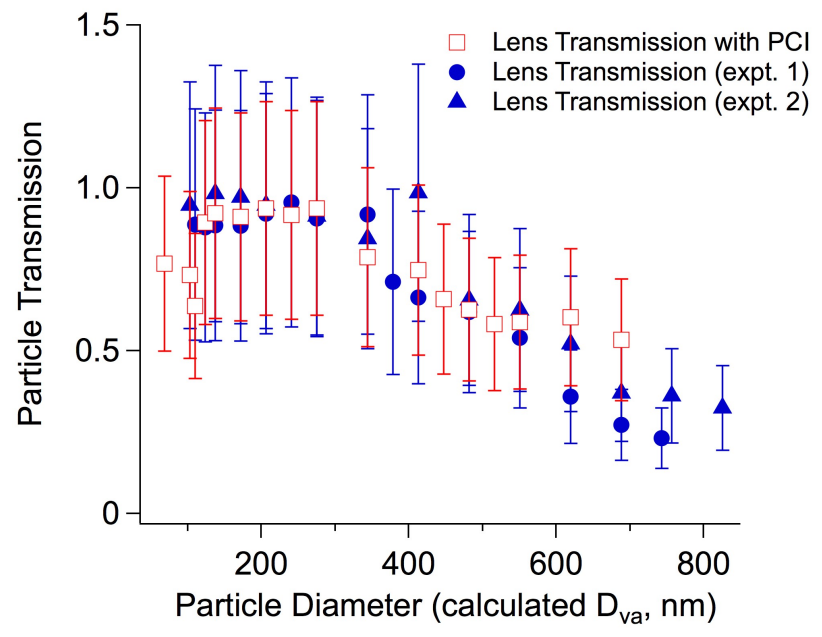

Figure S1: Lens transmission curves with and without the PCI for $\mathrm{NH}_{4} \mathrm{NO}_{3}$ particles. Error bars are the propagated uncertainty based on $10 \%$ uncertainty in CPC counts and $30 \%$ uncertainty in AMS mass loadings. The two lens transmission experiments without the PCI were carried out before and after the NETCARE summer aircraft campaign, respectively. 


\subsubsection{Methanesulfonic acid (MSA) calibration and fragmentation pattern}

After the method of Zorn et al. (2008), we determined the fragmentation pattern for methanesulfonic acid (MSA) under the operating conditions of our HR-ToF-AMS by utilizing the unique MSA fragment $\mathrm{CH}_{3} \mathrm{SO}_{2}{ }^{+}$(m/z 78.99), which was well resolved from organic fragments at the same nominal mass (Figure S2). To account for the total MSA mass peaks containing carbon and sulfur were included (Table S1, major isotopes of "family-CS" species are not shown), as well as other carbonaceous and sulfur containing peaks that are usually associated with AMS organics or sulfate. As shown in Table S2 the default HR-ToFAMS fragmentation table (in PIKA v1.16) was modified based on the average fragmentation pattern in our instrument, such that contributions from MSA to peaks usually associated with organic species and sulfate were accounted for (i.e., the MSA contribution was subtracted from organics and sulfate). The fragmentation pattern on MSA is known to vary with vaporizer temperature (Zorn et al., 2008), and therefore efforts were made to carry out the MSA calibrations under the same instrumental conditions as were used for ambient measurements (i.e., the same vaporizer current and after calibration of the vaporizer temperature with sodium nitrate). The sensitivity of our HR-ToF-AMS to MSA relative to nitrate $\left(\mathrm{RIE}_{\mathrm{MSA}}\right)$ was determined to be $1.33 \pm 0.05$ (Figure S3, right), which is similar to estimated values used in other studies (e.g., Zorn et al., 2008).

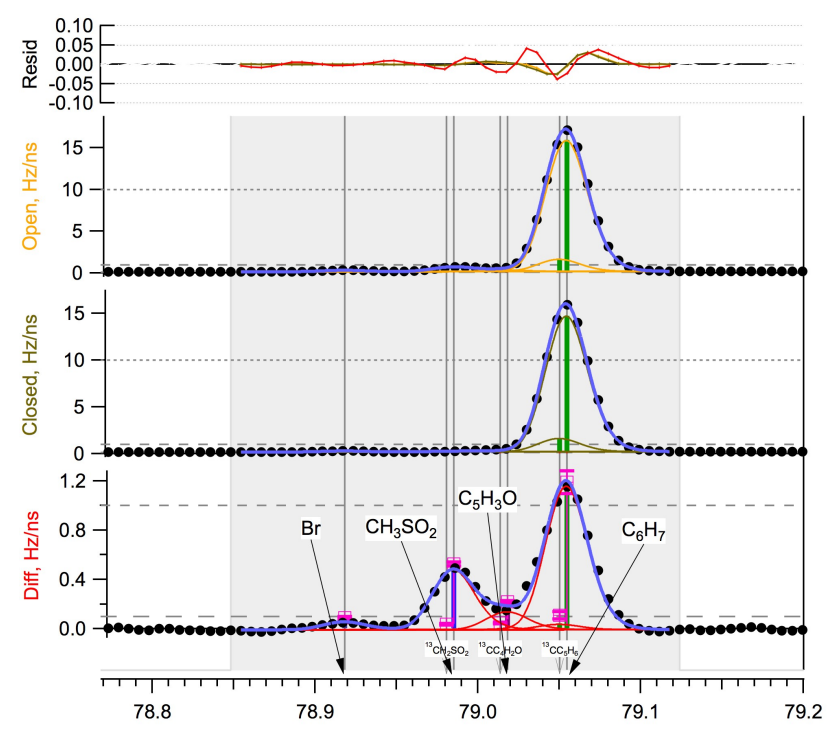

Figure S2: Average mass spectral data (open, closed and difference) for $\mathrm{m} / \mathrm{z} 79$ acquired during the case study flight. Shown are the peak fits for $\mathrm{CH}_{3} \mathrm{SO}_{2}{ }^{+}, \mathrm{C}_{6} \mathrm{H}_{7}{ }^{+}$and other minor species including $\mathrm{Br}^{+}$and $\mathrm{C}_{5} \mathrm{H}_{3} \mathrm{O}^{+}$. The fragmentation table for MSA was based on $\mathrm{CH}_{3} \mathrm{SO}_{2}{ }^{+}$as shown in Table $\mathrm{S} 2$. 
Table S1: Carbon and sulfur containing ions contributing to MSA mass

\begin{tabular}{cc}
\hline HR Ion & $\mathbf{m} / \mathbf{z}$ \\
\hline $\mathrm{CH}_{3} \mathrm{~S}^{+}$ & 47.00 \\
$\mathrm{CSO}^{+}$ & 59.97 \\
$\mathrm{CHSO}^{+}$ & 60.98 \\
$\mathrm{CH}_{2} \mathrm{SO}^{+}$ & 61.98 \\
$\mathrm{CH}_{3} \mathrm{SO}^{+}$ & 92.99 \\
$\mathrm{CH}_{2} \mathrm{SO}_{2}^{+}$ & 77.98 \\
$\mathrm{CH}_{3} \mathrm{SO}_{2}^{+}$ & 79.99 \\
$\mathrm{CH}_{4} \mathrm{SO}_{3}^{+}$ & 95.99 \\
\hline
\end{tabular}

Table S2: HR fragmentation table for MSA

\begin{tabular}{|c|c|c|c|}
\hline HR Ion & Methanesulfonic acid & Organics & Sulfate \\
\hline $\mathrm{CH}^{+}$ & $0.072 \cdot \mathrm{CH}_{3} \mathrm{SO}_{2}{ }^{+}$ & $\mathrm{CH}^{+}-\mathrm{MSA}\left(\mathrm{CH}^{+}\right)$ & \\
\hline $\mathrm{CH}_{2}^{+}$ & $0.32 \cdot \mathrm{CH}_{3} \mathrm{SO}_{2}^{+}$ & $\mathrm{CH}_{2}^{+}-\operatorname{MSA}\left(\mathrm{CH}_{2}^{+}\right)$ & \\
\hline $\mathrm{CH}_{3}^{+}$ & $2.55 \cdot \mathrm{CH}_{3} \mathrm{SO}_{2}^{+}$ & $\mathrm{CH}_{3}^{+}-\operatorname{MSA}\left(\mathrm{CH}_{3}^{+}\right)$ & \\
\hline $\mathrm{CH}_{4}^{+}$ & $0.046 \cdot \mathrm{CH}_{3} \mathrm{SO}_{2}^{+}$ & $\mathrm{CH}_{4}^{+}-\operatorname{MSA}\left(\mathrm{CH}_{4}^{+}\right)$ & \\
\hline $\mathrm{CHO}^{+}$ & $0.22 \cdot \mathrm{CH}_{3} \mathrm{SO}_{2}^{+}$ & $\mathrm{CHO}^{+}-\mathrm{MSA}\left(\mathrm{CHO}^{+}\right)$ & \\
\hline $\mathrm{CH}_{2} \mathrm{O}^{+}$ & $0.080 \cdot \mathrm{CH}_{3} \mathrm{SO}_{2}^{+}$ & $\mathrm{CHO}_{2}^{+}-\mathrm{MSA}\left(\mathrm{CHO}_{2}^{+}\right)$ & \\
\hline $\mathrm{CH}_{3} \mathrm{O}^{+}$ & $0.67 \cdot \mathrm{CH}_{3} \mathrm{SO}_{2}^{+}$ & $\mathrm{CHO}_{3}^{+}-\operatorname{MSA}\left(\mathrm{CHO}_{3}^{+}\right)$ & \\
\hline $\mathrm{CH}_{4} \mathrm{O}^{+}$ & $0.14 \cdot \mathrm{CH}_{3} \mathrm{SO}_{2}^{+}$ & $\mathrm{CHO}_{4}^{+}-\mathrm{MSA}\left(\mathrm{CHO}_{4}^{+}\right)$ & \\
\hline $\mathrm{SO}^{+}$ & $0.71 \cdot \mathrm{CH}_{3} \mathrm{SO}_{2}^{+}$ & & $\mathrm{SO}^{+}-\mathrm{MSA}\left(\mathrm{SO}^{+}\right)$ \\
\hline $\mathrm{HSO}^{+}$ & $0.057 \cdot \mathrm{CH}_{3} \mathrm{SO}_{2}^{+}$ & & $\mathrm{HSO}^{+}-\mathrm{MSA}\left(\mathrm{HSO}^{+}\right)$ \\
\hline $\mathrm{H}_{2} \mathrm{SO}^{+}$ & $0.017 \cdot \mathrm{CH}_{3} \mathrm{SO}_{2}^{+}$ & & $\mathrm{H}_{2} \mathrm{SO}^{+}-\mathrm{MSA}\left(\mathrm{H}_{2} \mathrm{SO}^{+}\right)$ \\
\hline $\mathrm{SO}_{2}^{+}$ & $0.59 \cdot \mathrm{CH}_{3} \mathrm{SO}_{2}^{+}$ & & $\mathrm{SO}_{2}^{+}-\operatorname{MSA}\left(\mathrm{SO}_{2}^{+}\right)$ \\
\hline $\mathrm{HSO}_{2}^{+}$ & $0.40 \cdot \mathrm{CH}_{3} \mathrm{SO}_{2}^{+}$ & & $\mathrm{HSO}_{2}^{+}-\mathrm{MSA}\left(\mathrm{HSO}_{2}^{+}\right)$ \\
\hline $\mathrm{H}_{2} \mathrm{SO}_{2}^{+}$ & $0.04 \cdot \mathrm{CH}_{3} \mathrm{SO}_{2}^{+}$ & & $\mathrm{H}_{2} \mathrm{SO}_{2}^{+}-\mathrm{MSA}\left(\mathrm{H}_{2} \mathrm{SO}_{2}^{+}\right)$ \\
\hline $\mathrm{HSO}_{3}^{+}$ & $0.44 \cdot \mathrm{CH}_{3} \mathrm{SO}_{2}^{+}$ & & $\mathrm{HSO}_{3}^{+}-\mathrm{MSA}\left(\mathrm{HSO}_{3}^{+}\right)$ \\
\hline
\end{tabular}
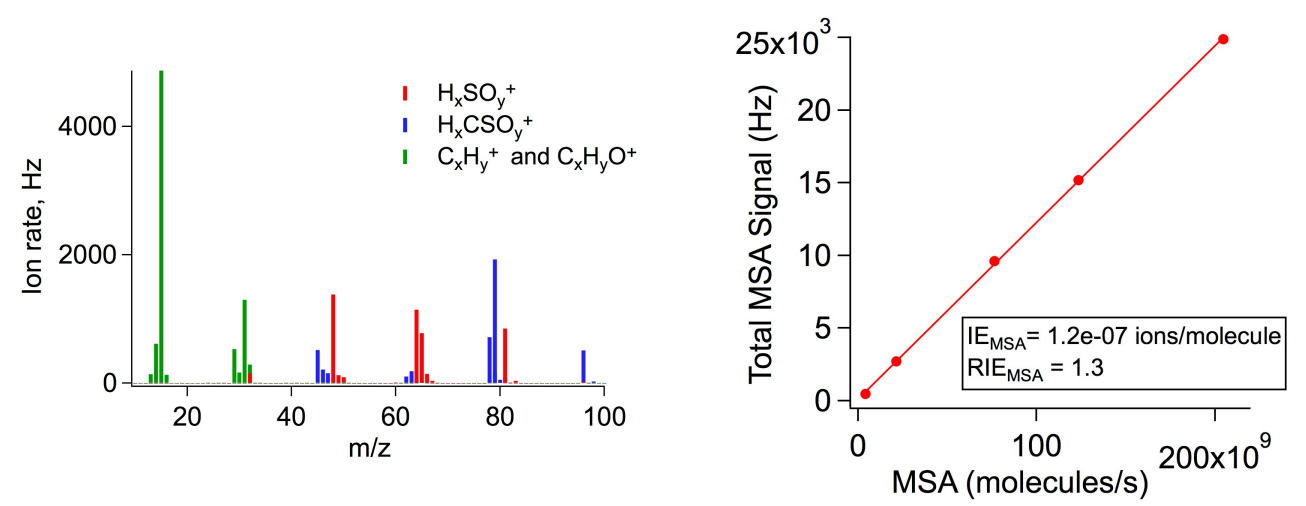

Figure S3: Family-coloured HR methanesulfonic acid mass spectrum (left). A representative calibration curve for MSA for mono-disperse $300 \mathrm{~nm}$ particles, corrected for doubly charged particles (right). The possibility of significant evaporation of MSA in the sampling lines or the AMS inlet, during the calibration, was ruled out by comparison of the AMS-derived vacuum aerodynamic diameter for MSA with the mobility diameter selected for using the differential mobility analyser (DMA). 


\section{Model results from WRF}

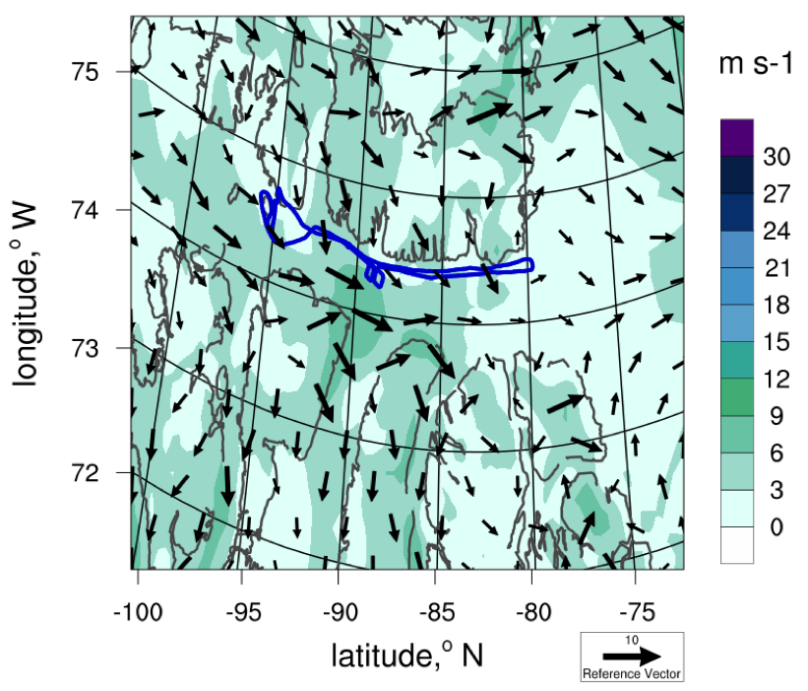

Figure S4: Surface wind speed (contours) and wind direction (arrows) predicted by WRF at 21:00 UTC on July 12, 2014. The flight track is shown in blue for reference. 


\section{Supplemental Results}

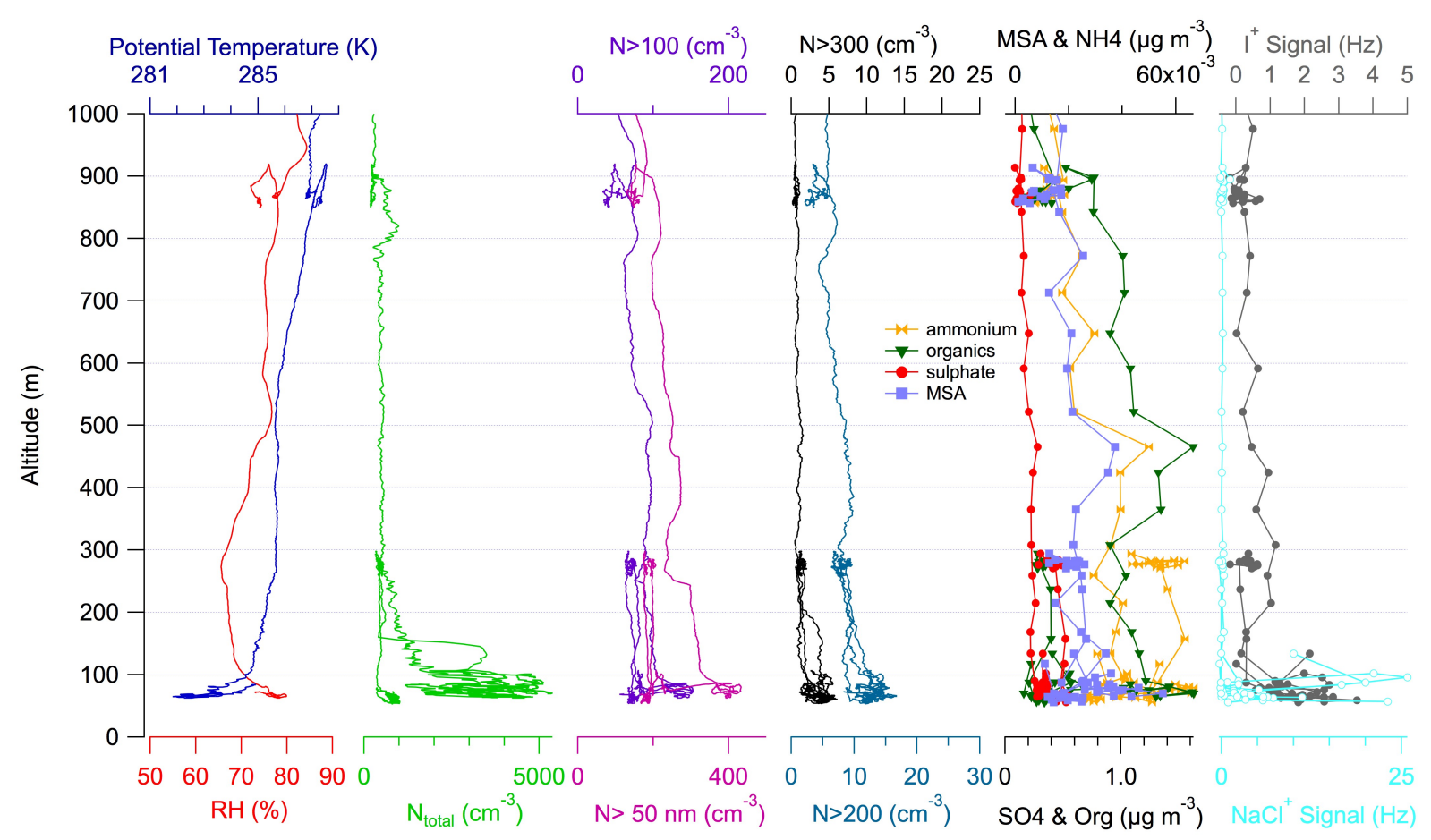

Figure S5: Summary of vertical profiles for the lowest $1 \mathrm{~km}$ during the eastern-most profile over Lancaster Sound, during the period of time in which particle growth was observed. $\mathrm{N}_{\text {total }}$ corresponds to the total particle numbers from $5 \mathrm{~nm}$ to $\sim 1 \mu \mathrm{m}$. Sea salt and iodine tracers are confined to the inversion layer, along with the larger accumulation mode particles $\left(\mathrm{N}_{>200}\right.$ and $\mathrm{N}_{>300}$ ) that are present largely in the inversion. In contrast, OA, MSA, and numbers of Aitken and small accumulation mode particles (i.e., approximately $\mathrm{N}_{>50}$ ) appear above the inversion layer suggesting that some mixing above the inversion layer has occurred. 


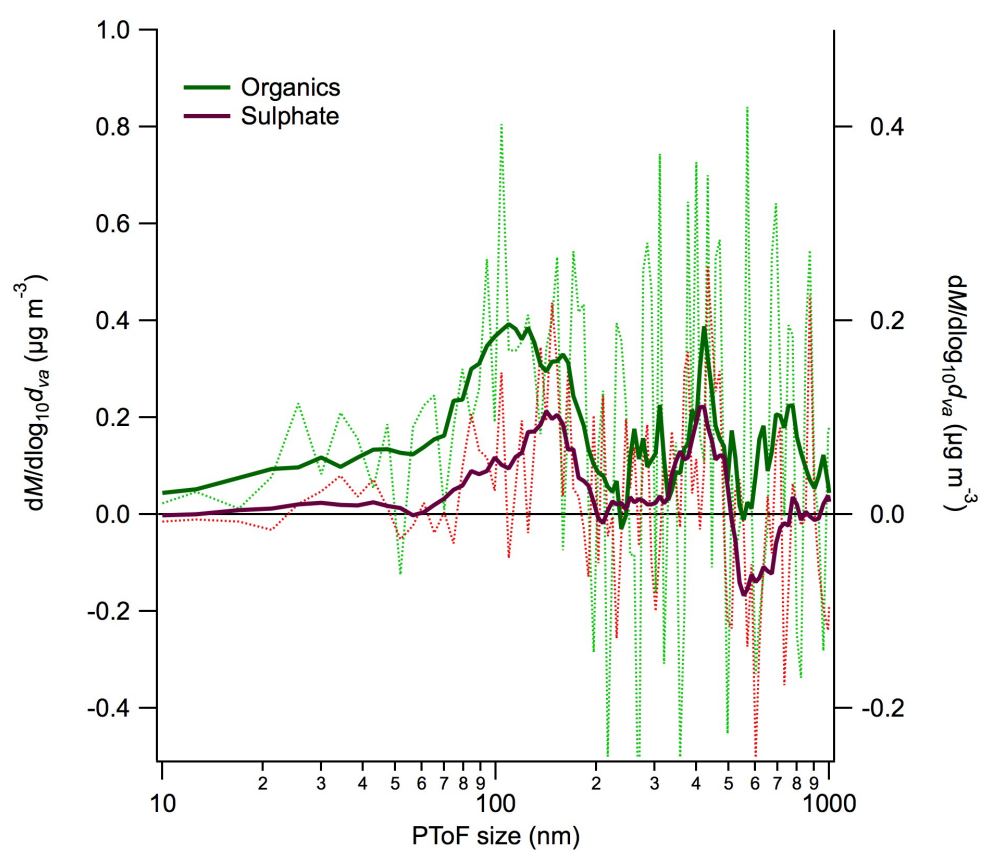

Figure S6: Average organic aerosol (left axis) and sulphate (right axis) particle-time-of-flight (epToF) size distributions during the growth event. Dashed lines represent raw data, solid lines represent a 4-point smoothing.
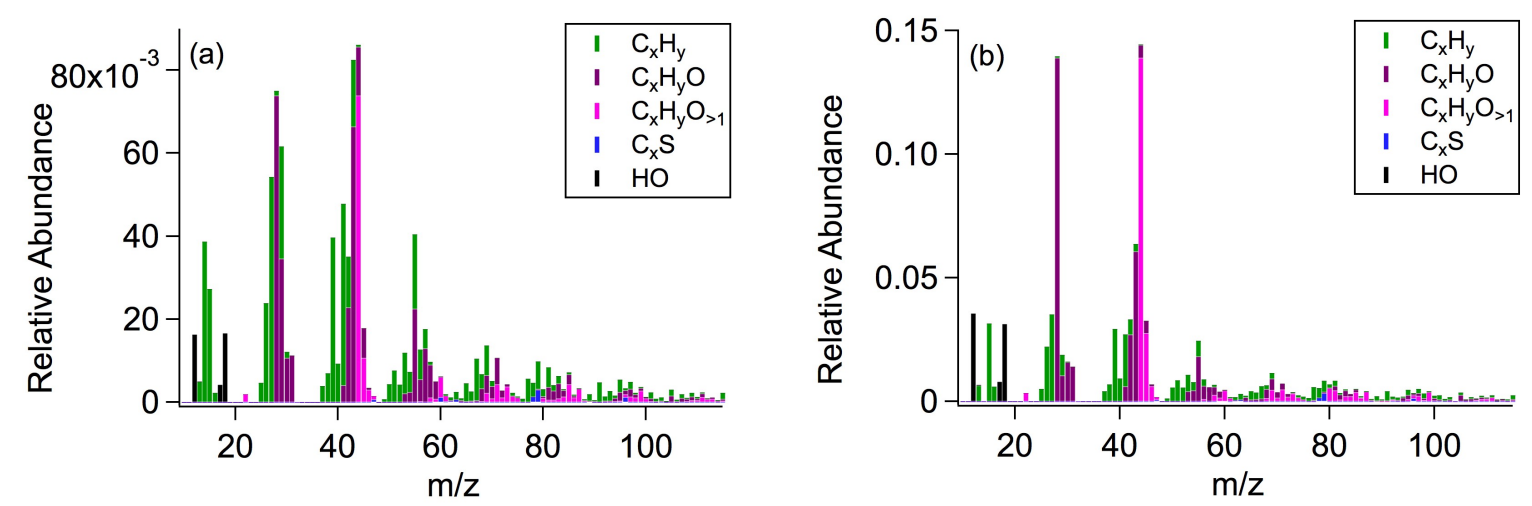

Figure S7: Average family-coloured mass spectrum for OA during the growth event (a) and at other times during the July 12, 2014 flight (b). 

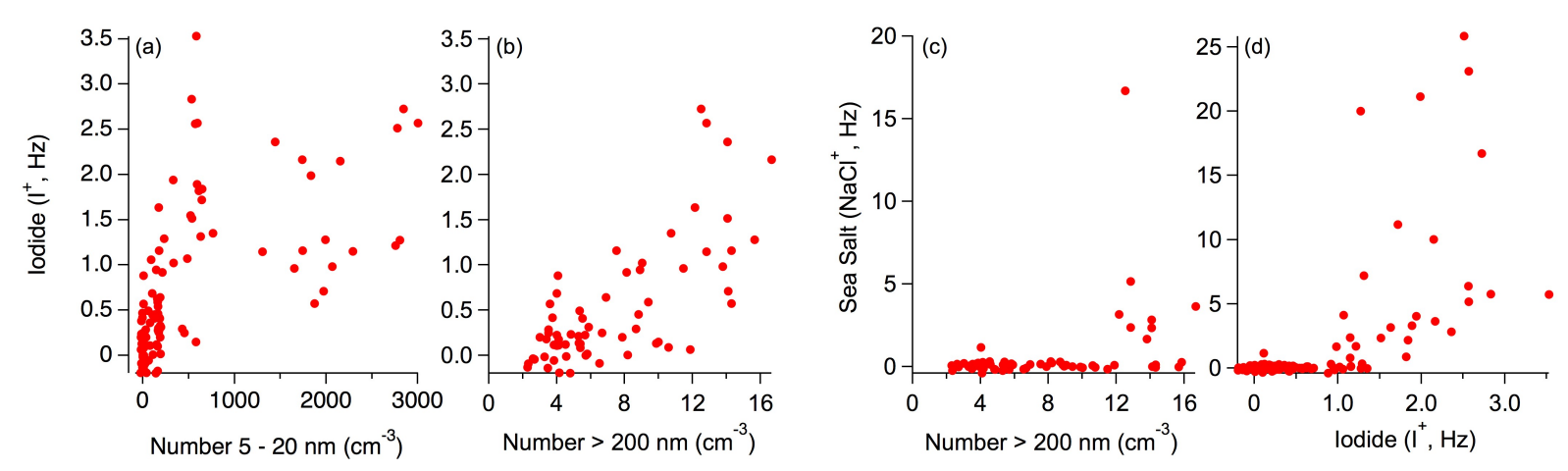

Figure S8: Correlations related to sea salt and iodine tracers during the case study period. (a) Iodine and the number of nucleation mode particles. (b) Iodine and the number of larger accumulation mode particles, greater than $200 \mathrm{~nm}$ in diameter. (c) Sea salt and the number of larger accumulation mode particles, greater than $200 \mathrm{~nm}$ in diameter. (d) Sea salt and iodine tracers.

\section{References}

Canagaratna, M. R., Jimenez, J. L., Kroll, J. H., Chen, Q., Kessler, S. H., Massoli, P., Hildebrandt Ruiz, L., Fortner, E., Williams, L. R., Wilson, K. R., Surratt, J. D., Donahue, N. M., Jayne, J. T., and Worsnop, D. R.: Elemental ratio measurements of organic compounds using aerosol mass spectrometry: characterization, improved calibration, and implications, Atmospheric Chemistry and Physics, 15, 253-272, doi:10.5194/acp-15-2532015, URL http://www . atmos-chem-phys .net/15/253/2015/, 2015.

Hayden, K. L., Sills, D. M. L., Brook, J. R., Li, S.-M., Makar, P. A., Markovic, M. Z., Liu, P., Anlauf, K. G., O'Brien, J. M., Li, Q., and McLaren, R.: Aircraft study of the impact of lake-breeze circulations on trace gases and particles during BAQS-Met 2007, Atmospheric Chemistry and Physics, 11, $10173-10$ 192, doi:10.5194/acp-11-10173-2011, URL http://www . atmos-chem-phys.net/11/10173/2011/, 2011.

Zorn, S. R., Drewnick, F., Schott, M., Hoffmann, T., and Borrmann, S.: Characterization of the South Atlantic marine boundary layer aerosol using an aerodyne aerosol mass spectrometer, Atmospheric Chemistry and Physics, 8, 4711-4728, 2008. 